Check for updates

Cite this: RSC Adv., 2019, 9, 7688

\title{
In silico design of mimosine containing peptides as new efficient chelators of aluminum $\uparrow$
}

\author{
J. I. Mujika, (D) a G. Dalla Torre, (iD) ab J. I. Lachowicz (D) ${ }^{\mathrm{c}}$ and X. Lopez (D) *a
}

The design of new and efficient chelators that can remove aluminium(III), a metal with increasing recognition as a potential toxic agent, from biological systems is an area of high therapeutic relevance. In the present paper, we present an extensive computational study of a new promising type of these chelators based on mimosine containing peptides. The reason to choose mimosine is that the sidechain of this residue is similar to deferiprone, a ligand known to tightly interact with highly-valent metals, and in particular with Al(III). In this article we analyze systematically, using a combination of methods that include $Q M / M M M D$ simulations, how the size and sequence of the polypeptides can alter the fundamental binding patterns to aluminum, in comparison with the binding to deferiprone. Particular attention is given towards the identification of the smallest peptide that interacts efficiently with aluminum, since polypeptide size is a fundamental factor to allow a given polypeptide to efficiently cross the cell membrane. The results indicate that the longest peptides, with 8 or 9 amino acids, show no difficulties interacting with $\mathrm{Al}(\mathrm{II})$ in an optimum arrangement. By contrast, when the peptide contains five or six amino acids Al(III) is pentacoordinated, reducing the stability of the resultant complex. In summary, our study demonstrates that the mimosine containing peptides can efficiently coordinate highly valent metals such as $\mathrm{Al}(\mathrm{III})$, with a subtle dependence of the binding on the specific chain-lengths of the polypeptide. We believe that the present study sheds light on the adequacy of this new type of chelator towards aluminum binding.

Received 10th December 2018 Accepted 26th February 2019

DOI: $10.1039 / c 8 r a 10139 f$

rsc.li/rsc-advances established in at least three diseases: dialysis dementia, ${ }^{4}$ osteomalacia $^{5}$ and microcytic anaemia without iron deficiency. ${ }^{6,7}$ The principal symptoms of its toxicity are: diminished intellectual function, forgetfulness, inability to concentrate; speech and language impairment; personality changes, altered mood, depression; dementia; visual and/or auditory hallucinations; osteomalacia with fracturing; motor disturbances; weakness, fatigue, mainly related to microcytic anaemia; epileptic seizures.

In the case of aluminum intoxication, $\mathrm{Al}(\mathrm{III})$ chelation is performed to reduce $\mathrm{Al}$ (III) organ levels (especially in bone) and reduce toxicity of $\mathrm{Al}(\mathrm{III})$. This may benefit patients with endstage renal disease or with neurodegenerative disorders as well as patients suffering from neurobehavioral toxicity due to prolonged occupational Al(III) exposure. ${ }^{8}$ In chronic hemodialysis patients chelation therapy is indicated at serum $\mathrm{Al}(\mathrm{III})$ concentration higher than $80 \mu \mathrm{g} \mathrm{L}^{-1}$. $^{9}$ Previously, the only available chelator for treating $\mathrm{Al}(\mathrm{III})$ overloaded patients was deferoxamine (DFO) originally developed for decorporation of iron in transfusional iron overload in thalassemia and sickle cell anemia patients. The hydrophilic chelator DFO is poorly absorbed in the gastrointestinal tract and must be administered parenterally, either subcutaneously, intramuscularly, or intravenously. DFO is not an ideal chelating agent due to the high frequency of side effects, the need for parenteral administration Physics Center (DIPC), P.K. 1072, 20080 Donostia, Euskadi, Spain. E-mail: xabier. lopez@ehu.es

Universidade do Porto, Porto, Portugal

${ }^{c}$ University of Cagliari, Department of Chemical and Geological Sciences, Cittadella Universitaria, Monserrato, Italy

$\dagger$ Electronic supplementary information (ESI) available: Additional structura details of $\mathrm{Al} \cdot \mathrm{DFP}_{3}$ and $\mathrm{Al} \cdot \mathrm{Pept}^{9}{ }_{3 \mathrm{G}}$, RMSD of $\mathrm{MD}$, radius of gyration, individua hydrogen bond interactions, PM6 and DFT comparison. See DOI: 10.1039/c8ra10139f 
restricting off-clinic self-administration, and high price. However, despite the advent of alternative chelators for $\mathrm{Al}(\mathrm{III})$ chelation, DFO still has an important role in treatment of $\mathrm{Al}(\mathrm{III})$ intoxication. ${ }^{10}$ An extensive body of evidence from in vitro and experimental animal studies demonstrates the potential of hydroxypyridinone derivatives from both series to reduce $\mathrm{Al}(\mathrm{III})$ toxicity and promote $\mathrm{Al}(\mathrm{III})$ decorporation. The most promising compound among the hydroxypyridinones for iron chelation after extensive animal experimentation, 1,2-dimethyl-3-hydroxy4-pyridone (deferiprone, DFP, see Scheme 1) went into clinical trial initially for iron decorporation and is licenced in USA and Europe for treatment of iron overload in thalassemia major. Even if less efficient in aluminum coordination respect to DFO, DFP is orally administrated, somewhat less toxic, and much cheaper than DFO. ${ }^{11}$ DFP was extensively studied during past years by Hider ${ }^{12-14}$ and Santos, ${ }^{15-17}$ who prepared its oligodentate derivatives mostly as $\mathrm{Fe}$ (III) chelators, which ultimately found new application as $\mathrm{Ga}^{68}$ complexes for PET immagining. ${ }^{14,18,19}$ Recently, Abbate et al. reported novel targeting peptides incorporating DFP as the iron(III) chelating units. ${ }^{20}$

Nevertheless, there is an urgent need for other, more efficient, less toxic and cheaper aluminum chelators. In this paper, we proposed for the first time that mimosine containing peptides could be a promising candidate as efficient chelators of aluminum. Mimosine [ $\beta$-[ $N$-(3-hydroxy-4-oxypyridyl)]- $\alpha$-aminopropionic acid] (see Scheme 1) is a non-protein amino acid found in the members of Mimosoideae family. It has been found to have various biological activities such as antibacterial, anti-cancer, antiinflammation, anti-fibrosis, anti-influenza, anti-virus, herbicidal and insecticidal activities. ${ }^{21}$ In the 90's mimosine was studied as an inducer of G1/S phase arrest $\mathrm{t}^{22}$ and over the past years of active research, mimosine evolved as promising agent for the treatment of cancer disease. Mimosine dipeptides and tetrapeptides were synthesised as neuraminidase ${ }^{23}$ tyrosinase ${ }^{23,24}$ and cyclooxygenase ${ }^{24}$ inhibitors.

The presence of the carbonyl and alcohol groups in the side chain of mimosine makes this residue an effective ligand for binding metal ions, and thus mimosine can bind divalent, trivalent and tetravalent transition metal ions. ${ }^{25-27}$ Due to its structural similarity to DFP it is expected a high affinity towards $\mathrm{Al}(\mathrm{III})$ as well. Moreover, joining three mimosine residues in the same peptide could enhance significantly aluminum complex

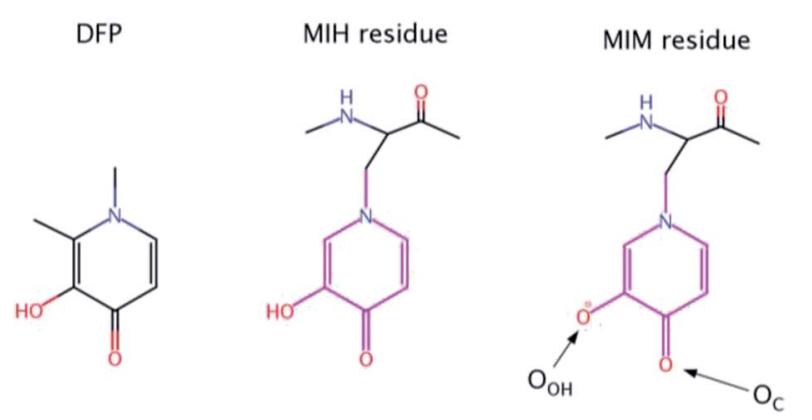

Scheme 1 Chemical structures of Deferiprone (DFP) and mimosine residue in its neutral $(\mathrm{MIH})$ and ionic (MIM) form. The labels of the two $\mathrm{O}$ atoms of mimosine residue are also illustrated. stability, and obtain new class of chelating agents based on nonproteinogenic amino acids. However, the size of the peptide might be critical for its successful absorption into the organism.

To the best of our knowledge the activity of mimosine containing peptides as chelator of $\mathrm{Al}(\mathrm{III})$ has not been investigated yet. The present study aims to find the smallest mimosine containing peptide that interacts tightly with $\mathrm{Al}(\mathrm{III})$. To do that, we employed state-of-the-art computational methods to characterize systematically the complexation of $\mathrm{Al}(\mathrm{III})$ to several peptides of different lengths that contain three mimosine residues (shown in Fig. 1). The geometric and energetic stabilities of all the Al-Pept complexes were analyzed, paying special attention on the interactions between the cation and the peptide. We also compare all these data with the complex formed by DFP. All this information allows us to propose for the first time the shortest mimosine-based peptide with the highest coordination stability toward $\mathrm{Al}(\mathrm{III})$ ions. This will certainly open the field to a new type of chelators, not only for $\mathrm{Al}(\mathrm{III})$, but for highly valent metals showing similar coordination features as $\mathrm{Al}(\mathrm{III})$, e.g. lanthanides with their peculiar magnetic properties used in PET imagining.

\section{Methodology}

\section{Systems set-up}

The complexation of $\mathrm{Al}(\mathrm{III})$ to eight mimosine containing peptides of different length has been investigated following the

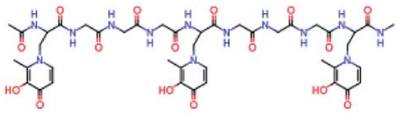

M-G-G-G-M-G-G-G-M Pept $^{9}{ }_{3 G}$

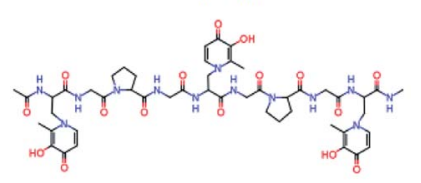

M-G-P-G-M-G-P-G-M $\mathrm{Pept}_{\text {GPG }}^{9}$

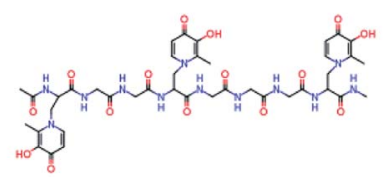

M-G-G-M-G-G-G-M Pept $^{8}{ }_{2 \mathrm{G}-3 \mathrm{G}}$

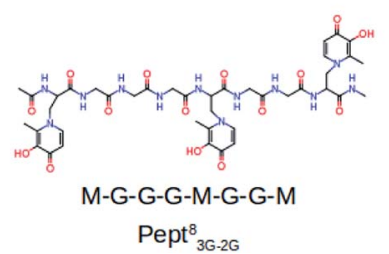

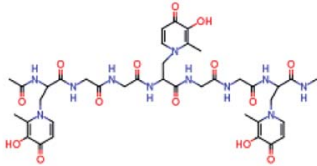

M-G-G-M-G-G-M

Pept $^{7}$

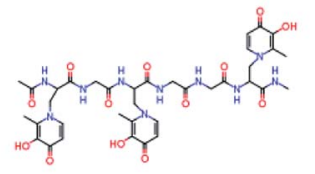

M-G-M-G-G-M $\mathrm{Pept}_{\text {G-2G }}^{6}$

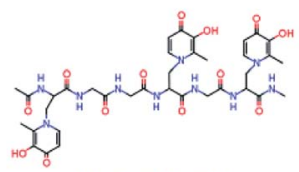

M-G-G-M-G-M Pept $^{6}{ }_{2 G-G}$

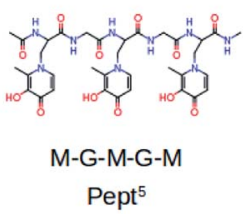

Fig. 1 Molecular structures of the studied eight mimosine containing peptides. 


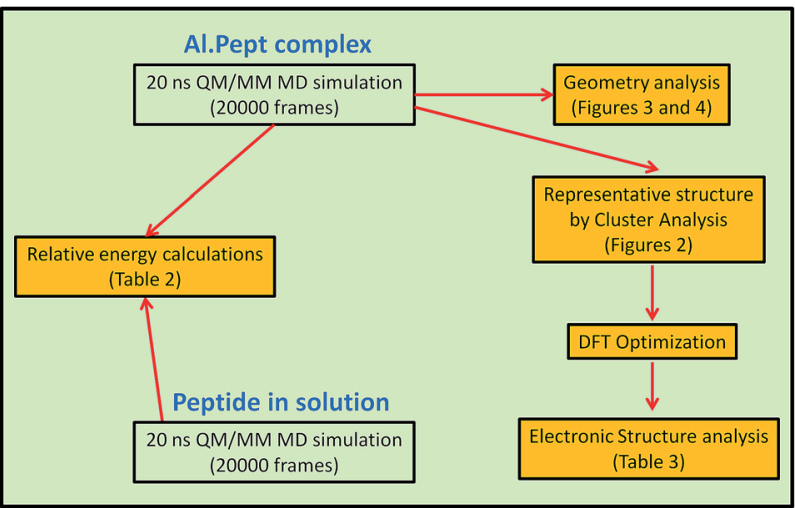

Scheme 2 Theoretical protocol used throughout this study (described in Methodology section) for each of the structures shown in Fig. 1.

protocol shown in Scheme 2. All peptides contain three mimosine residues (sequences presented in Fig. 1) and they differ in the two linkers connecting the mimosine residues: the two longest peptides contain nine amino acids so that their two linkers are made of three amino acids: in $\mathrm{Pept}^{9}{ }_{3 \mathrm{G}}$ the linker includes three glycine residues, whereas in $\mathrm{Pept}^{9}{ }_{\mathrm{GPG}}$ a proline was inserted into the peptide in order to support turn formation upon metal complexation. Next, two eight residues-long peptides were built, what implies two different linkers: GG and GGG in Pept ${ }^{8}{ }_{2 \mathrm{G}-3 \mathrm{G}}$ and the reverse in Pept ${ }_{3 \mathrm{G}-2 \mathrm{G}}^{8}$. Next, Pept ${ }^{7}$ includes two symmetric linkers made of two glycine residue each. The six amino acid long peptides involve two asymmetric linkers, namely $\mathrm{G}$ and GG in Pept ${ }_{\mathrm{G}-2 \mathrm{G}}$ and the opposite in $\mathrm{Pept}^{6}{ }_{\text {G-G G }}$. Finally, Pept ${ }^{5}$ is the shortest peptide, with just a glycine residue at each of the two linkers. In all peptides, the $\mathrm{N}$ - and C-terminals were neutralized by adding methyl groups.

The Al-Pept ${ }_{3 \mathrm{G}}^{9}$ system was the first one to be built, for what the $\mathrm{Fe}(\mathrm{III})-\mathrm{N}$-derivatized 3-hydroxy-4-pyridiones comple $^{28}$ was used as initial template. Once the complex was set up and equilibrated by molecular dynamics simulation, its structure was used as template to build the initial structure for the complexes formed by Pept ${ }_{\mathrm{GPG}}^{9}$, Pept ${ }_{2 \mathrm{G}-3 \mathrm{G}}$ and Pept ${ }_{3 \mathrm{G}-2 \mathrm{G}}$. In a similar manner, previously equilibrated $\mathrm{Al} \cdot \mathrm{Pept}$ structures were used to build the initial structures for the complexes of the remaining shorter peptides.

\section{Molecular dynamics simulations}

Each of the eight systems listed about was sampled by QM/MM molecular dynamics simulation using the Amber14 suit of programs. ${ }^{29}$ The choice of running QM/MM MD simulations was based on two main reasons: (a) lack of reliable MM parameters for the non-standard mimosine amino acid, and (b) description of the metal binding site by a quantum methods allows polarization, what it is expected to be relevant with a highly charged cation such as $\mathrm{Al}(\mathrm{III})$. The PM6 semiempirical method ${ }^{30}$ was chosen to treat the $\mathrm{Al}(\mathrm{III})$ binding site, since it provides a good compromise between calculation speed and accuracy.

The LEaP program was used to build the topology of each system, for which Amber ff14SB all-atom force field parameters $^{31}$ were chosen for standard amino acids. The parameters for
MIM needed to build the system (but not used during the QM/ MM MD simulations) were obtained with Antechamber. Periodic boundary conditions were applied in all directions using an octahedron cell, with a minimal distance between the peptide and the wall of the cell set to $10 \AA$. The structures were solvated by a box of TIP3P-type water molecules. ${ }^{32}$

First a MM minimization was carried out to relax the solvent, in which the Al-Pept complex was restrained. Then, in order to keep the initial rearrangement, a second minimization was performed restraining only the three mimosine residues and $\mathrm{Al}(\mathrm{III})$. Next, the system was heated to $300 \mathrm{~K}$ by a 1 ns-long equilibration defining a canonical thermodynamic ensemble (NVT), and using the Langevin thermostat to couple the temperature of the system (collision frequency of $1.0 \mathrm{ps}^{-1}$ ). Again, the Al-Pept solute was restrained. All this calculations were carried out at MM level.

The QM part was treated with the PM6 semi-empirical method and includes the side chains of the three unprotonated MIM residues (pink region depicted in Scheme 1) and $\mathrm{Al}(\mathrm{III})$, so that the total charge of the QM part was always neutral. The Amber ff14SB force field was employed to describe the remaining part of the system.

Once the system was heated, the QM/MM MD simulations were carried out without applying any restraint and keeping the condition at the heating stage, that is, NVT ensemble and the Langevin thermostat to couple the temperature of the system (collision frequency of $1.0 \mathrm{ps}^{-1}$ ). All bonds involving hydrogens were constrained with the SHAKE algorithm, ${ }^{33}$ allowing for an integration time step of 2 fs. Long-range electrostatics were calculated using the smooth particle mesh Ewald (PME) method,,$^{34,35}$ and a cutoff of $8 \AA$ was defined for all nonbonded interactions. The first $1 \mathrm{~ns}$ of the QM/MM MD simulation were leave to equilibrate the system, whereas the remaining $20 \mathrm{~ns}$ of simulations were employed for the analysis. From each QM/MM MD simulation, representative structures were extracted by cluster analysis using the cpptraj utility in Amber14. ${ }^{36}$

\section{Relative binding energies}

From the QM/MM MD simulations, relative binding energies of the eight peptides towards $\mathrm{Al}(\mathrm{III})$ were computed according to the next reaction:

$$
\begin{aligned}
\mathrm{Al} \cdot\left[\mathrm{Pept}_{x} \cdot(\mathrm{MIM})_{3}\right]+\mathrm{Pept}_{y} \cdot(\mathrm{MIH})_{3} \leftrightarrow & \mathrm{Al} \cdot\left[\mathrm{Pept}_{y} \cdot(\mathrm{MIM})_{3}\right]+ \\
& \operatorname{Pept}_{x} \cdot(\mathrm{MIH})_{3}
\end{aligned}
$$

where Pept $x$ and Pept ${ }_{y}$ refer to peptides of different sequence. This reaction therefore estimates the difference in energy between the interaction of Al(III) with Pept $_{x}$ and Pept $y$. In other words, it will give us the relative stability between the two complexes. Based on reaction (1), the relative binding enthalpies between the complexes formed by Pept ${ }_{x}$ and Pept $y$ with $\mathrm{Al}(\mathrm{III})$ are calculated as:

$$
\begin{aligned}
\Delta \Delta H_{\text {Binding }}{ }^{x-y}= & \langle E\rangle_{\mathrm{Al} \cdot\left[\text { Pept }_{y} \cdot(\mathrm{MIM})_{3}\right]}+\langle E\rangle_{\text {Pept }_{x} \cdot(\mathrm{MIH})_{3}} \\
& -\langle E\rangle_{\mathrm{Al}^{\prime} \cdot\left[\text { Pept }_{x} \cdot(\mathrm{MIM})_{3}\right]}-\langle E\rangle_{\text {Pept }_{y} \cdot(\mathrm{MIH})_{3}}
\end{aligned}
$$

where $\langle E\rangle$ stands for the average potential energy extracted from the corresponding QM/MM MD simulation. A positive value of 
$\Delta \Delta H_{\text {Binding }}{ }^{x-y}$ will mean that $\mathrm{Al}(\mathrm{III})$ has a larger affinity towards Pept $_{x}$, whereas a negative value will suggest a larger affinity towards Pept ${ }_{y}$. The Pept ${ }_{3 \mathrm{G}}$ system was taken as reference.

Nevertheless, the computation of the $\Delta \Delta H_{\text {Binding }}{ }^{x-y}$ values is not straightforward since the number of explicit water molecules differs at each MD simulation (and therefore with unbalance number of interactions), making unrealistic a direct comparison between them. In order to overcome this problem, the potential energies were determined replacing the explicit water molecules by a Generalized Born implicit solvent ${ }^{37}$ as implemented in Amber 14. The structures saved every 5 ps of each simulation were used to calculate the $\langle E\rangle$ average potential energies with implicit solvent.

The estimation of the relative binding energies (eqn (2)) requires the energies of the apoform of the peptides as well. 20 ns long QM/MM MD simulations were also performed for the eight apoform of the peptides using an implicit solvent. The computed RMSDs (shown in Fig. S4†) indicate that the structures were equilibrated at the end of the simulations. Note that unlike when the mimosine residues interact with $\mathrm{Al}$ (III), we assume the mimosine residues protonated in solution. This assumption relies on the $\mathrm{p} K_{\mathrm{a}}$ values estimated by cyclic voltammetry $^{38}$ for the two oxygen atoms of deferiprone: 3.5 and 10.2. Based on these values, it is clear that the two oxygen atoms should be as a keto and hydroxide group, respectively, and therefore, the later protonated. However, when they interact with $\mathrm{Al}(\mathrm{III})$, it is expected a significant drop of their $\mathrm{p} K_{\mathrm{a}}$ values, as computed for some oxygen-containing standard amino acids interacting with $\mathrm{Al}(\mathrm{III}){ }^{39}$ Consequently, it is reasonable to assume that the hydroxide group is deprotonated when complexated to $\mathrm{Al}(\mathrm{III})$, but protonated in the apoform.

\section{DFT binding energies}

Optimizations were carried out in solution with Gaussian16 ${ }^{40}$ at B3LYP-D3(BJ)/6-31+G(d) and using the IEFPCM solvation model. ${ }^{41}$ In addition, the DFT energies were refined with single point calculations at the B3LYP-D3(BJ)/6-311++G(3df,2p) level of theory. Representative structure of each system (shown in Fig. 2), determined by cluster analysis on the MD trajectories (using the cpptraj facility ${ }^{36}$ in Amber14), were used as initial structures for the optimizations. To confirm that optimized structures were real minima on the potential energy surfaces, frequency calculations were carried out at the same level of theory. All structures showed positive force constants for all normal modes of vibration. The frequencies were then used to evaluate the zero-point vibrational energy (ZPVE) and thermal ( $T$ $=298 \mathrm{~K}$ ) vibrational corrections to the Gibbs free energies within the harmonic oscillator approximation. To calculate the entropy, the different contributions to the partition function were evaluated using the standard statistical mechanics expressions in the canonical ensemble and the harmonic oscillator and rigid rotor approximation.

The next reaction was defined to evaluate the formation energies of the eight $\mathrm{Al} \cdot \mathrm{Pept}$ complexes and $\mathrm{Al} \cdot \mathrm{DFP}_{3}$ :

$$
\begin{aligned}
& {\left[\mathrm{Al}\left(\mathrm{H}_{2} \mathrm{O}\right)_{6}\right]^{3+}(\mathrm{aq},}1 \mathrm{M})+\mathrm{Pept}^{0}(\mathrm{aq}, 1 \mathrm{M}) \leftrightarrow \\
& {\left[\mathrm{Al} \cdot\left(\mathrm{Pept}^{3-}\right)\right]^{0}(\mathrm{aq}, 1 \mathrm{M})+3 \mathrm{H}_{2} \mathrm{O}(\mathrm{aq}, 1 \mathrm{M}) } \\
&+3 \mathrm{H}_{3} \mathrm{O}^{+}(\mathrm{aq}, 1 \mathrm{M}) \\
& {\left[\mathrm{Al}\left(\mathrm{H}_{2} \mathrm{O}\right)_{6}\right]^{3+}(\mathrm{aq}, 1 \mathrm{M})+3 \mathrm{DFP}^{0}(\mathrm{aq}, 1 \mathrm{M}) \leftrightarrow } \\
& {\left[\mathrm{Al} \cdot\left(\mathrm{DFP}^{-}\right)_{3}\right]^{0}(\mathrm{aq}, 1 \mathrm{M})+3 \mathrm{H}_{2} \mathrm{O}(\mathrm{aq}, 1 \mathrm{M}) } \\
&+3 \mathrm{H}_{3} \mathrm{O}^{+}(\mathrm{aq}, 1 \mathrm{M})
\end{aligned}
$$

Notice that the peptides (and DFP) are neutral (protonated) in solution but deprotonated in the complexes, so three hydronium molecules are included as products in order to balance the reaction. The enthalpy in solution corresponding to the binding of the ligand to $\mathrm{Al}(\mathrm{III})$ is therefore calculated as:

$$
\begin{aligned}
\Delta H_{\mathrm{aq}}= & H_{\mathrm{aq}}\left(\mathrm{Al} \cdot \mathrm{Lig}^{\text {deprot }}\right)+3 H_{\mathrm{aq}}\left(\mathrm{H}_{2} \mathrm{O}\right)+3 H_{\mathrm{aq}}\left(\mathrm{H}_{3} \mathrm{O}\right) \\
& -H_{\mathrm{aq}}\left(\mathrm{Al}\left(\mathrm{H}_{2} \mathrm{O}\right)_{6}\right)-H_{\mathrm{aq}}\left(\mathrm{Lig}^{\mathrm{prot}}\right)+\Delta n R T \ln (24.46)
\end{aligned}
$$

where Lig can be a mimosine containing peptide or three deferiprone molecules (the superscript specifies its protonation state). Since the enthalpies are determined using an ideal gas at $1 \mathrm{~atm}$ as the standard state, the last term in eqn (5) corresponds to the volume change due to the transformation from 1 atm to $1 \mathrm{M}$ in solution, where $\Delta n$ refers to the change in the number of species in the reaction $(\Delta n=5$ and 3 in reaction (3) and (4),
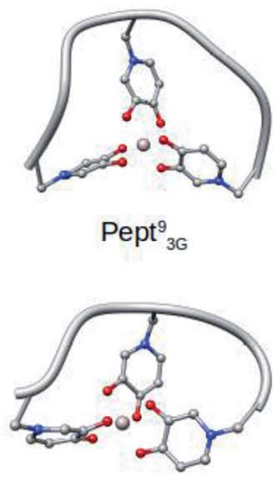

Pept $^{7}$

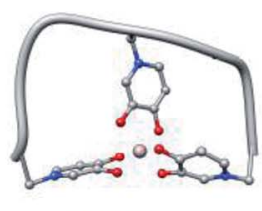

Pept $^{9}{ }_{\text {GPG }}$

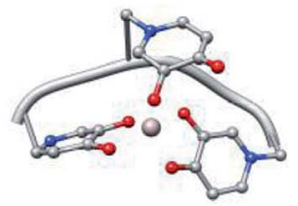

Pept $_{\text {G-2G }}^{6}$

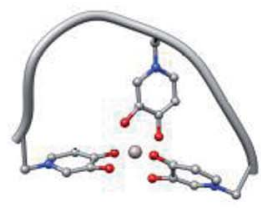

Pept $^{8}{ }_{2 \mathrm{G}-3 \mathrm{G}}$

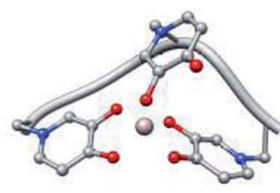

$\operatorname{Pept}^{6}{ }_{2 \mathrm{G}-\mathrm{G}}$

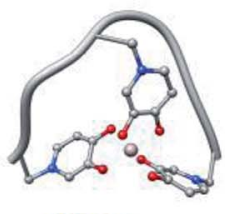

$\mathrm{Pept}^{8}{ }_{3 \mathrm{G}-2 \mathrm{G}}$

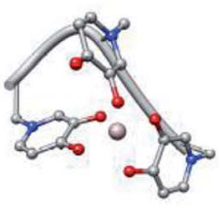

Pept $^{5}$

Fig. 2 Representative snapshots of the MD simulations of the eight Al-Pept complexes determined by cluster analysis. 
respectively). In a similar way, the free energy of the complexes is determined as:

$$
\begin{aligned}
\Delta G_{\mathrm{aq}}= & G_{\mathrm{aq}}\left(\mathrm{Al} \cdot \mathrm{Lig}^{\text {deprot }}\right)+3 G_{\mathrm{aq}}\left(\mathrm{H}_{2} \mathrm{O}\right)+3 G_{\mathrm{aq}}\left(\mathrm{H}_{3} \mathrm{O}\right) \\
& -G_{\mathrm{aq}}\left(\mathrm{Al}\left(\mathrm{H}_{2} \mathrm{O}\right)_{6}\right)-G_{\mathrm{aq}}\left(\mathrm{Lig}^{\text {prot }}\right)+\Delta n R T \ln (24.46) \\
& +3 R T \ln (55.34)
\end{aligned}
$$

where the last term is the entropic factor that accounts for the concentration of $55.34 \mathrm{M}$ of three waters in liquid water.

Prediction of solvation energies of small charged ions such as $\mathrm{H}_{3} \mathrm{O}^{+}$using a continuum solvation models implies a significant deviation from the real value. In order to alleviate this problem, the Gibbs free energy of the hydronium ion was calculated as:

$$
G_{\mathrm{aq}}\left(\mathrm{H}_{3} \mathrm{O}\right)=G_{\text {gas }}+\Delta G_{\text {solv }}(\exp )
$$

where $G_{\text {gas }}$ is calculated at the DFT level as explained before and $\Delta G_{\text {solv }}$ is the experimental solvation energy. $\left(-103.45 \mathrm{kcal} \mathrm{mol}^{-1}\right){ }^{42}$

Moreover, a correction term in the free energies is introduced to account for the hydronium concentration, which depends on the $\mathrm{pH}$ :

$$
G_{\mathrm{pH}}=m(-\mathrm{pH}) R T \ln (10)
$$

where physiological $\mathrm{pH}$ is 7.4 and $m=3$ is the number of hydroniums.

In order to validate PM6, all this procedure was repeated with this semiempirical method and the results between DFT and PM6 compared (PM6 results included in ESI $\dagger$ ). In overall, the geometries and energies computed with both level of theories are comparable, so we believe PM6 provides meaningful results.

\section{Results}

The sequences of the eight peptides studied herein are shown in Fig. 1. The name of each peptide is composed by a superscript indicating the length of the peptide, and a subscript referring to the linker sequences (one for symmetric peptides, and two for the asymmetric ones). For instance, the Pept ${ }^{9}{ }_{\text {GPG }}$ system is nine residues long and contains three mimosine residues, which are spaced with GPG sequence linkers. The two oxygen atoms of mimosine residue are denoted as $\mathrm{O}_{\mathrm{C}}$ and $\mathrm{O}_{\mathrm{OH}}$, and correspond to the carbonyl and hydroxyl oxygen atoms, respectively (Scheme 1). Along the body text, the atom names include a subscript to specify the atom type and a superscript to refer to the residue number.

The RMSD computed on the QM/MM molecular dynamic simulations for the eight $\mathrm{Al} \cdot \mathrm{Pept}$ complexes (shown in Fig. $\mathrm{S} 3 \dagger$ ) demonstrate that all systems are equilibrated after the 20 ns run of production. Representative snapshots of each simulation are shown in Fig. 2. First, the structural data of each complex is analyzed, with special attention on the metal coordination shell. Next, the binding energy values of each $\mathrm{Al} \cdot$ Pept complex are discussed, and finally, these complexes compared with $\mathrm{Al} \cdot \mathrm{DFP}_{3}$.

\section{Structural stability of the first Al(III) coordination shell}

The optimum coordination shell of $\mathrm{Al}(\mathrm{III})$ is the one presented in $\mathrm{Al} \cdot \mathrm{DFP}_{3}$ (see Fig. $\mathrm{S} 1 \dagger$ ), ${ }^{43}$ with the cation octahedral and the three MIM residues bidentate through the $\mathrm{O}_{\mathrm{C}}$ and $\mathrm{O}_{\mathrm{OH}}$ atoms. In order to investigate if this arrangement is maintained by all the peptides studied, some geometrical parameters are analyzed: (i) distances between $\mathrm{Al}(\mathrm{III})$ and the six $\mathrm{O}$ atoms of the three MIM residues (Table 1 and Fig. 3), (ii) all possible $\mathrm{O}-\mathrm{Al}-\mathrm{O}$ angles formed by the six oxygen atoms (Fig. 4 and Table S3†). The complexes are presented from the longest to the shortest peptides.

$\mathbf{P e p t}^{\mathbf{9}_{\text {GG }}}$ and Pept ${ }_{\text {GPG }}$. The two longest peptides form octahedral complexes with $\mathrm{Al}(\mathrm{III})$, as the values of the six $\mathrm{Al}-\mathrm{O}^{\mathrm{Mim}}$ distances, which are very stable throughout the entire simulations (Table 1), demonstrate. Interestingly, although both oxygen atoms are deprotonated, the distances Al-oxygen are not equivalent and $\mathrm{O}_{\mathrm{C}}$ presents longest distances than $\mathrm{O}_{\mathrm{OH}}$ : the average values of the $\mathrm{Al}-\mathrm{O}_{\mathrm{C}}$ and $\mathrm{Al}-\mathrm{O}_{\mathrm{OH}}$ distances are $c a .1 .97 \AA$ and $1.93 \AA$, respectively, with both Pept $^{9}$. Moreover, in overall the average distances are very similar with both $\mathrm{Pept}^{9}$ peptides, except the $\mathrm{Al}-\mathrm{O}_{\mathrm{C}}{ }^{5}$ distance, which is about $0.02 \AA$ longer for Pept $^{9}{ }_{\text {GPG }}(1.982 \AA)$.

Table 1 Average and standard deviation (in $\AA$ ) of the six distances between the $\mathrm{O}_{\mathrm{C}}$ and $\mathrm{O}_{\mathrm{OH}}$ atoms of the three mimosine residues and $\mathrm{Al}(\mathrm{II})$ computed along the QM/MM MD simulation trajectories of the Al.Pept complexes ${ }^{a}$

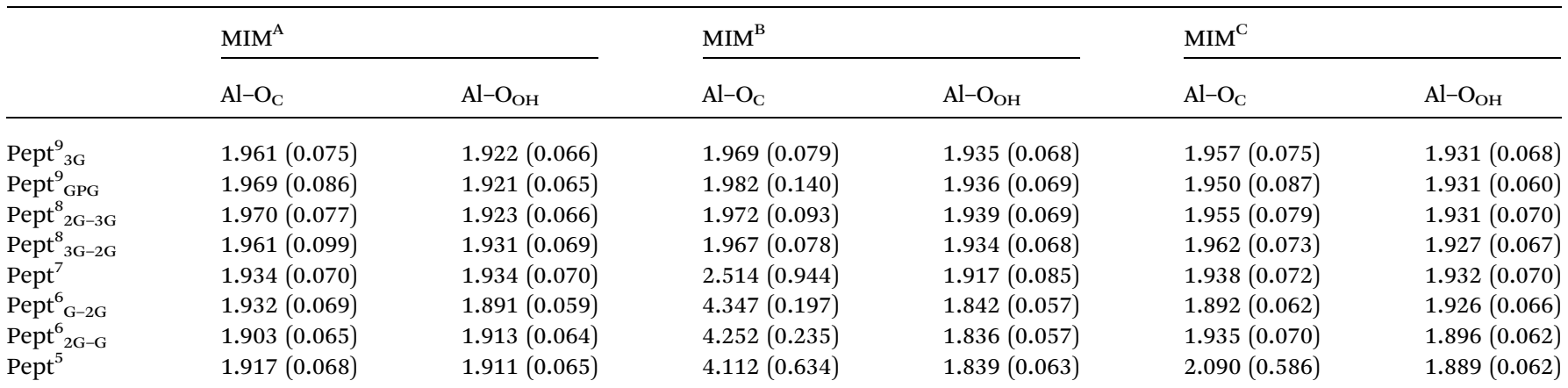

${ }^{a}$ Since the indexes of the three mimosine residues differ on the systems, they are referred to as A, B and C for the first, central and last mimosine in the corresponding sequence shown in Fig. 1. 

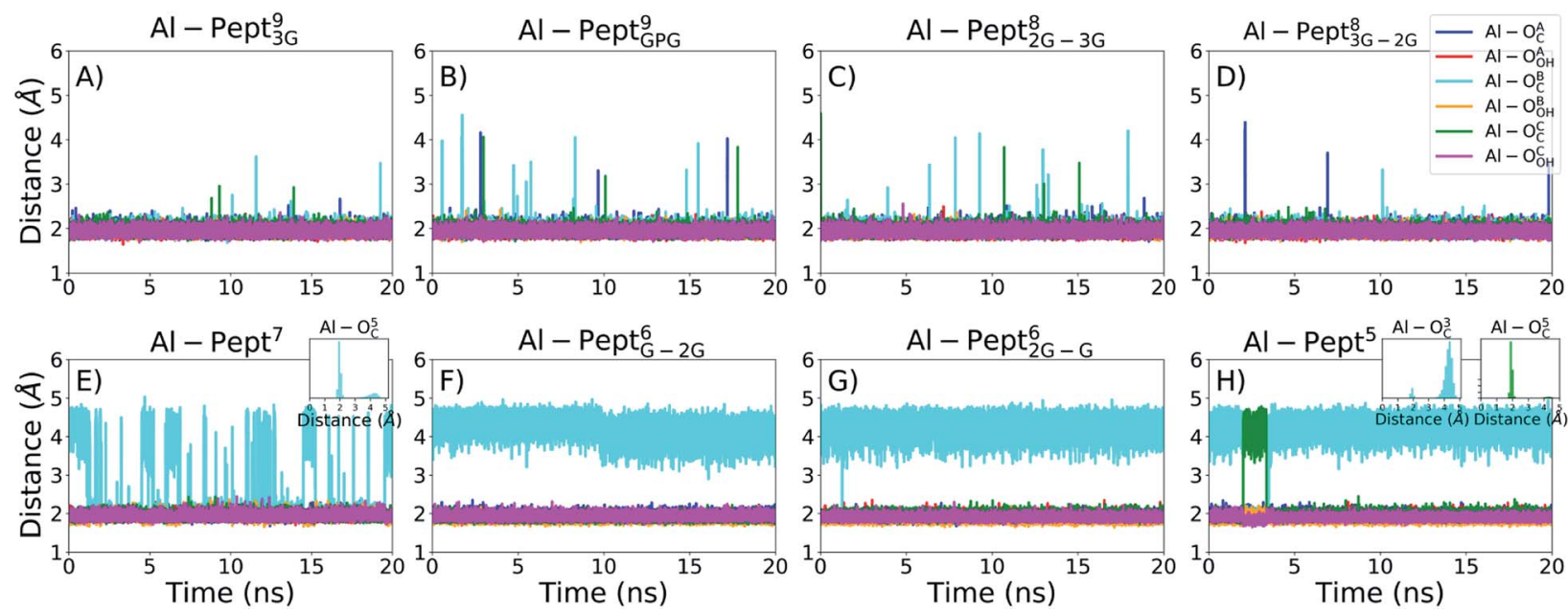

Fig. 3 Evolution of the distances between $\mathrm{Al}(\mathrm{III})$ and the two $\mathrm{O}_{\mathrm{C}}$ and $\mathrm{O}_{\mathrm{OH}}$ atoms of the mimosine residues during the QM/MM MD simulations.

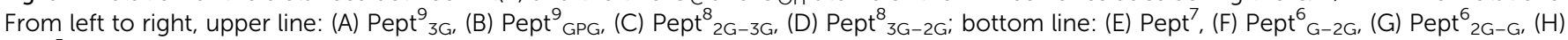
$\mathrm{Pept}^{5}$. The colour scheme is shown in the upper-right panel. Since the indexes of the three mimosine residues differ on the systems, they are referred to as $A, B$ and $C$ for the first, central and last mimosine in the corresponding sequence shown in Fig. 1.

The $\mathrm{O}^{\mathrm{Mim}}-\mathrm{Al}-\mathrm{O}^{\mathrm{Mim}}$ angles computed for the two $\mathrm{Al} \cdot \mathrm{Pept}^{9}$ complexes confirm that $\mathrm{Al}(\mathrm{III})$ adopts a nearly octahedral arrangement. We can observe in Fig. 4 that $\mathrm{O}^{\mathrm{Mim}}-\mathrm{Al}-\mathrm{O}^{\mathrm{Mim}}$ angles are divided in two sets: a prevalent one centered on 90 degrees and a second one centered on 160 degrees, which correspond to equatorial and axial angles, respectively, in a typical octahedral arrangement. A deeper analysis of the angles (Table S3†) shows that during the simulation of the $\mathrm{Al} \cdot \mathrm{Pept}^{9}{ }_{3 \mathrm{G}}$ complex, 11 out of the 15 angles are in the $86-92$ degree range (the range is slightly wider for $\mathrm{Al} \cdot \mathrm{Pept}_{\mathrm{GPG}}{ }_{\mathrm{GP}}$ : 82-94 degrees), very close to the ideal value of 90 degrees for equatorial angles. $\mathrm{O}_{\mathrm{OH}}{ }^{1}-\mathrm{Al}-\mathrm{O}_{\mathrm{OH}}{ }^{9}$ is the only angle out of these ranges, with average values of 101 degrees on both complexes. On the other hand, the values of the remaining three angles, namely the $\mathrm{O}_{\mathrm{C}}{ }^{1}-\mathrm{Al}-\mathrm{O}_{\mathrm{C}}{ }^{9}, \mathrm{O}_{\mathrm{OH}}{ }^{1}-\mathrm{Al}-\mathrm{O}_{\mathrm{OH}}{ }^{5}$ and $\mathrm{O}_{\mathrm{C}}{ }^{5}-\mathrm{Al}-\mathrm{O}_{\mathrm{OH}}{ }^{9}$, are in the
164-168 degree range, thus near to the optimum value for axial angles. Hence, both Pept ${ }^{9}$ peptides are long enough to allow the mimosine side chains to adopt a near-octahedral arrangement (see Fig. 2).

$\mathbf{P e p t}^{\mathbf{8}}{ }_{2 \mathrm{G}-3 \mathrm{G}}$ and Pept ${ }^{\mathbf{8}}{ }_{3 \mathrm{G}-2 \mathrm{G}}$. The Al-O distances calculated for the complexes of these two peptides are similar to those of Pept ${ }^{9}$ peptides, i.e., ca. $1.97 \AA$ for the three $\mathrm{Al}-\mathrm{O}_{\mathrm{C}}$ distances and $1.93 \AA$ for the $\mathrm{Al}-\mathrm{O}_{\mathrm{OH}}$ distances. The average values of the angles computed for the $\mathrm{Al} \cdot \mathrm{Pept}^{8}{ }_{2 \mathrm{G}-3 \mathrm{G}}$ complex are also very similar to the ones calculated for Pept ${ }^{9}$ peptides: a maximum deviations of 7 degrees is observed with respect to the angles computed on the $\mathrm{Al} \cdot \mathrm{Pept}_{3 \mathrm{G}}{ }^{\mathrm{G}}$ complex. The similarity is maintained with the three axial angles. However, some differences are found in the $\mathrm{Al} \cdot \mathrm{Pept}^{8}{ }_{3 \mathrm{G}-2 \mathrm{G}}$ complex, in which only seven angles lie between 86-95 degrees, and the remaining equatorial angles are in the
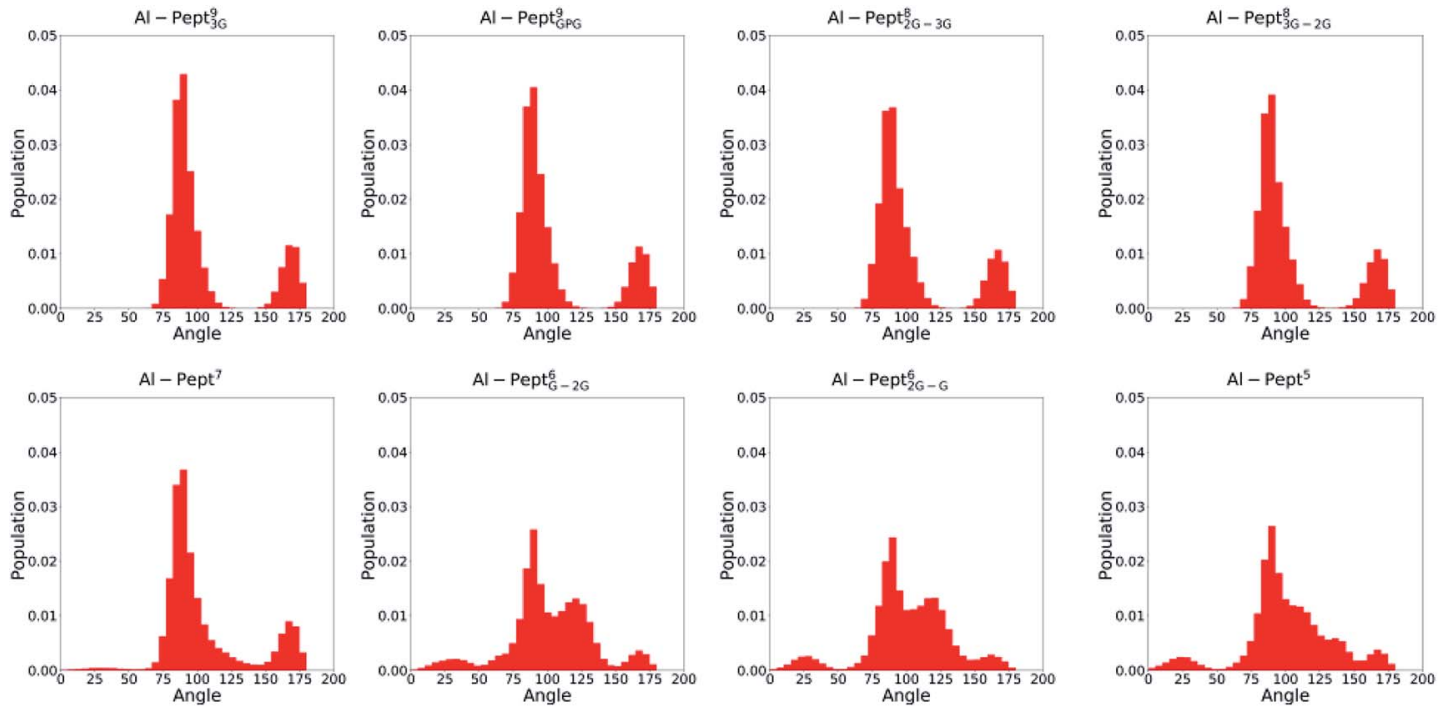

Fig. 4 Distribution of all $\mathrm{O}^{\mathrm{Mim}}-\mathrm{Al}-\mathrm{O}^{\mathrm{Mim}}$ angles computed along the QM/MM MD simulations trajectories of the eight Al-Pept complexes (sequences

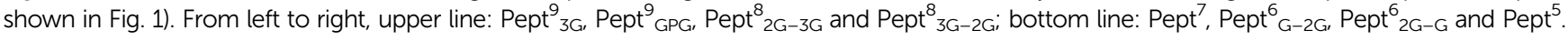


103-115 range, with larger standard deviations. Moreover, the values of the three axial angles are smaller, with larger standard deviation. The origin of these differences is not due to a change in the metal coordination mode, but rather to a spatial rearrangement of the ligands that interchanges some equatorial and axial angles. The metal complex structure remains octahedral and the distribution of the angles (Fig. 4) is invariable respect to $\mathrm{Pept}^{9}$ peptides.

$\mathbf{P e p t}^{7}$. With this peptide the octahedral coordination mode is less favourable, since only five out of six $\mathrm{O}$ atoms are tightly bound to $\mathrm{Al}(\mathrm{III})$. $\mathrm{Al}-\mathrm{O}_{\mathrm{OH}}{ }^{4}$ presents the shortest distance $(1.917 \AA)$, while the distances between $\mathrm{Al}$ (III) and the four oxygen atoms of $\mathrm{MIM}^{1}$ and $\mathrm{MIM}^{7}$ are $1.93 \AA$. Unlike with the two $\mathrm{Pept}^{9}$ peptides, no clear difference between $\mathrm{O}_{\mathrm{C}}$ and $\mathrm{O}_{\mathrm{OH}}$ is observed. The remaining distance, $\mathrm{Al}-\mathrm{O}_{\mathrm{C}}{ }^{4}$, shows a remarkably longer average value (2.514 $\AA)$, with a larger deviation (0.944 $\AA$ ). As it can be observed in Fig. 3, the values of $\mathrm{Al}-\mathrm{O}_{\mathrm{C}}{ }^{4}$ distance fluctuates between $2 \AA$ and $4.5 \AA$. As shown in the histogram of the distance (small panel in Fig. 3E), two clear peaks are centered on $2 \AA$ and $4.5 \AA$, the former being predominant, without any significant intermediate value. Hence, $\mathrm{MIM}^{4}$ does not bind $\mathrm{Al}(\mathrm{III})$ tightly and fluctuates between being bidentate and monodentate (through $\mathrm{O}_{\mathrm{OH}}$ atom).

The distribution of the $\mathrm{O}-\mathrm{Al}-\mathrm{O}$ angles reflects such multiple conformations. Even if two clear peaks are located at 90 and 160 degrees, the angles population between these two peaks has increased, and it is not any more nearly zero (as in the simulations with larger peptides). Moreover, the peak of the axial angles has shifted to smaller values. At this point, the simulation suggests that $\mathrm{Pept}^{7}$ presents less stable octahedral arrangement, even if still this coordination mode is the most prevalent one (see below).

Pept $^{\mathbf{6}}{ }_{\mathbf{G}-2 \mathrm{G}}$, Pept ${ }^{\mathbf{6}}{ }_{\text {G-G }}$ and Pept ${ }^{5}$. The three shortest peptides exhibit a similar pattern during the MD simulations: five out of six mimosine oxygen atoms are tightly bound to $\mathrm{Al}(\mathrm{III})$, with average lengths of 1.8-1.9 $\AA$. By contrast, the $\mathrm{O}_{\mathrm{C}}$ atom of the central mimosine residue $\left(\mathrm{MIM}^{4}\right.$ in the two $\mathrm{Pept}^{6}$ peptides and $\mathrm{MIM}^{3}$ in $\mathrm{Pept}^{5}$ ) is clearly out of the metal coordination shell, with an average length of $c a .4 .2 \AA$. Even that $\mathrm{O}_{\mathrm{C}}{ }^{3}$ atom interacts with $\mathrm{Al}(\mathrm{III})$ for a short period of time during the $\mathrm{Al} \cdot \mathrm{Pept}^{5}$ simulation, during this period of simulation $\mathrm{O}_{\mathrm{C}}{ }^{5}$ atom leaves the $\mathrm{Al}(\mathrm{III})$ first coordination shell. Therefore, $\mathrm{Al}(\mathrm{III})$ appears always pentacoordinated with these three peptides: the two terminal mimosines are bidentate ligands, whereas the central one is a monodentate ligand.

The angles distribution computed on the MD simulations of the shortest three peptides are very similar and confirm that the octahedral arrangement of $\mathrm{Al}(\mathrm{III})$ is not possible due to the shortness of the peptides. The peak ascribed to the axial angles has lowered, and even if the peak located at around 90 degrees is still predominant, the angle distribution is significantly broader than with longer peptides.

\section{Al(III) coordination mode}

The analysis of the geometries has shown that the peptide length clearly influences the interaction of the peptide with $\mathrm{Al}(\mathrm{III})$. In order to quantify this trend, we calculated the
Table 2 On the left section of the table, percentages of snapshots extracted from the QM/MM MD simulations of the Al-Pept complexes with an octahedral $\mathrm{Al}(\mathrm{III})$, determined based on two criteria: (a) $\mathrm{Al}-\mathrm{O}$ distances shorter than $2.5 \AA$, and (b) presence of three axial angles (>150 degrees). On the right section of the table, relative binding enthalpies $\left(\Delta \Delta H_{\text {Binding }^{x-y}}\right.$, in $\left.\mathrm{kcal} \mathrm{mol}^{-1}\right)$ between the Mim-containing peptides of different sequence, taking the Al-Pept ${ }^{9}{ }_{3 G}$ complexes as reference. In the case of $\mathrm{Pept}^{7}$, the relative energies between the two coordination modes observed during its MD simulation (Al(III) octahedral or pentacoordinated) are also shown

\begin{tabular}{|c|c|c|c|c|}
\hline & $\%$ Oct (dist) & $\%$ Oct (angle) & \multicolumn{2}{|c|}{$\Delta \Delta H_{\text {Binding }}{ }^{x-y}$} \\
\hline $\operatorname{Pept}_{3 \mathrm{G}}^{9}$ & 100.0 & 98.0 & 0.0 & \\
\hline $\operatorname{Pept}^{9}{ }_{\text {GPG }}$ & 99.6 & 96.5 & 1.8 & \\
\hline $\operatorname{Pept}^{8}{ }_{2 \mathrm{G}-3 \mathrm{G}}$ & 99.8 & 94.2 & 2.5 & \\
\hline $\operatorname{Pept}_{3 G-2 G}^{8}$ & 99.9 & 93.1 & 1.7 & \\
\hline Pept $^{7}$ & 74.9 & 72.1 & 11.4 & $\begin{array}{l}9.4 \text { (C.N. }=6) \\
17.3 \text { (C.N. }=5\end{array}$ \\
\hline $\operatorname{Pept}^{6}{ }_{\mathrm{G}-2 \mathrm{G}}$ & 0.0 & 0.0 & 12.9 & \\
\hline $\operatorname{Pept}^{6}{ }_{2 \mathrm{G}-\mathrm{G}}$ & 0.0 & 0.1 & 13.9 & \\
\hline $\mathrm{Pept}^{5}$ & 0.1 & 2.2 & 20.0 & \\
\hline
\end{tabular}

coordination number (C.N.) of $\mathrm{Al}$ (III) along each MD simulation, which can be either 5 or 6 . In order to do that, two alternative geometrical criteria were defined to consider a frame from a trajectory octahedral: (i) six Al-O distances shorter than $2.5 \AA$, and (ii) if three axial O-Al-O angles are present (larger than 150 degrees). The results presented in Table 2 show the same trend for both criteria, although the percentages of C.N. $=6$ are slightly lower with the angle criteria.

During the corresponding QM/MM MD simulations, $\mathrm{Pept}^{9}$ and $\mathrm{Pept}^{8}$ bind an octahedral Al(III). According to the distance criterion, during almost all their simulations the C.N. is six. The percentage is slightly lower according to the angle criterion, $c a$. 97\% for the two $\mathrm{Pept}^{9}$ peptides and $94 \%$ for the two $\mathrm{Pept}^{8}$ peptides. The three shortest peptides, with five and six residues, do not form octahedral complexes with $\mathrm{Al}$ (III) ions (the percentage of frames with C.N. $=6$ is almost zero).

By contrast, the $\mathrm{Al} \cdot \mathrm{Pept}^{7}$ complex is the border line system, in which both C.N. $=5$ and C.N. $=6$ are highly sampled. However, C.N. $=6$ prevails during the MD simulation, with 72$75 \%$ of the structures with hexa coordination mode, whereas in the remaining $25-28 \%$ of snapshots the metal ion is pentacoordinated.

\section{Relative stability of the Al-Pept complexes}

The $\mathrm{Pept}^{9}{ }_{3 \mathrm{G}}$ peptide was taken as reference to estimate the relative binding energies ( $\left.\Delta \Delta H_{\text {Binding }}\right)$ of the eight peptides, which were computed from the QM/MM MD simulations of the apoform and holoforms of free peptides (see Methodology section). The results are presented in Table 2 .

The $\Delta \Delta H_{\text {Binding }}$ values indicate that there is a direct relationship between the length of the peptide, the stability of their $\mathrm{Al} \cdot$ Pept complexes, and the coordination mode of $\mathrm{Al}(\mathrm{III})$ : the complexes formed by the four longest peptides present similar energies and in all of them $\mathrm{Al}(\mathrm{III})$ is octahedral. The $\mathrm{Al} \cdot \mathrm{Pept}^{9}{ }_{3 \mathrm{G}}$ complex is the most stable one, followed by $\mathrm{Pept}^{8}{ }_{3 \mathrm{G}-2 \mathrm{G}}$ 


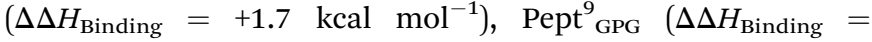
$\left.+1.8 \mathrm{kcal} \mathrm{mol}^{-1}\right)$ and $\operatorname{Pept}^{8}{ }_{2 \mathrm{G}-3 \mathrm{G}}\left(\Delta \Delta H_{\text {Binding }}{ }^{x-y}=\right.$ $+2.5 \mathrm{kcal} \mathrm{mol}^{-1}$ ).

The remaining four complexes are clearly less stable. Among them, $\mathrm{Al} \cdot \mathrm{Pept}^{7}$ is the most stable one, with $\Delta \Delta H_{\text {Binding }}=$ $+11.4 \mathrm{kcal} \mathrm{mol}^{-1}$. It must be pointed out that this is the relative energy computed with consideration of all snapshots extracted from the MD simulation. As described above, in the $\mathrm{Al} \cdot \mathrm{Pept}^{7}$ complex $\mathrm{Al}(\mathrm{III})$ is as either hexacoordinated (ca. $72 \%$ of the structures) or pentacoordinated ( $c a .28 \%$ ). When the relative energies are analysed separately, for each of the coordination mode, the $\Delta \Delta H_{\text {Binding }}$ value of hexacoordinated structures reduces to $+9.4 \mathrm{kcal} \mathrm{mol}^{-1}$, whereas the $\Delta \Delta H_{\text {Binding value of }}$ $\mathrm{Al}(\mathrm{III})-$ pentacoordinated complex increases to $+17.3 \mathrm{kcal} \mathrm{mol}^{-1}$.

The complexes formed by the two $\mathrm{Pept}^{6}$ peptides present

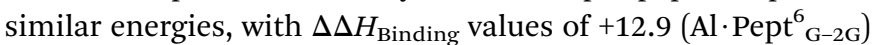
and $+13.9\left(\mathrm{Al} \cdot \mathrm{Pept}^{6}{ }_{2 \mathrm{G}-\mathrm{G}}\right) \mathrm{kcal} \mathrm{mol}^{-1}$. The $\mathrm{Al} \cdot \mathrm{Pept}^{5}$ is the less stable complex, with a $\Delta \Delta H_{\text {Binding }}$ value of $20.0 \mathrm{kcal} \mathrm{mol}^{-1}$.

The $\Delta \Delta H_{\text {Binding }}$ values not only depend on the stability of the $\mathrm{Al} \cdot$ Pept complexes, but also on the stability of the peptide in solution (see reaction (1)). The stability of the free peptides is difficult to quantify precisely, but it is reasonable to assume that the formation of hydrogen bonds may contribute to their stability, and therefore, the larger the number of hydrogen bonds formed by a peptide, the higher its stability. The list of all individual backbone hydrogen bond interactions during the QM/MM MD simulations of the peptides in solution and their lifetimes are shown in ESI. $\dagger$ The data collected reveals the total number of hydrogen bonds is low, not surprising for such a small peptides, even that a clear trend is observed: the longest peptides form more hydrogen bond interactions than the shortest ones. Among them, the only peptide with a significant number of interactions is Pept ${ }^{9}$ GPG peptide, due to the presence of the proline residues. On the other hand, in none of the $\mathrm{Al} \cdot$ Pept complexes hydrogen bond interactions were detected. Thus, we can conclude that the computed relative binding energies rely mainly on the stability of the $\mathrm{Al} \cdot$ Pept complexes.

\section{Comparison with deferiprone}

As pointed out in the Introduction, deferiprone (DFP) is a widely used $\mathrm{Al}(\mathrm{III})$ chelator, and therefore it is a good reference to determine whether the mimosine peptides can also play this role efficiently. With this aim, we compare the binding energies and metal binding site geometries between $\mathrm{Al} \cdot \mathrm{DFP}_{3}$ and the eight $\mathrm{Al}$-Pept studied herein. The structures were optimized by means of a high level DFT method, for which representative structures extracted from each QM/MM MD simulation were chosen as initial structure for the geometry optimizations. The $\Delta H_{\mathrm{aq}}$ and $\Delta G_{\mathrm{aq}}$ values associated to the Al-Pept complex formations were calculated according to reaction (3) and (4), and are shown in Table 3 . Moreover, as in Table 2, the relative $\Delta \Delta H_{\mathrm{aq}}$ and $\Delta \Delta G_{\mathrm{aq}}$ values, taking the $\mathrm{Al} \cdot \mathrm{Pept}^{9}{ }_{3 \mathrm{G}}$ complex as reference, are also presented.

The calculations of both $\Delta H_{\mathrm{aq}}$ and $\Delta G_{\mathrm{aq}}$ allow us to estimate as well the entropy associated to the complex formation. As it can be seen in Table 3, there are not significant deviations in the
Table 3 Enthalpies $\left(\Delta H_{\mathrm{aq}}\right)$ and Gibbs free energies $\left(\Delta G_{\mathrm{aq}}\right)$ in solution of the Al-Pept complexes computed at DFT level according to reaction (3), along with the values of the Al-DFP 3 complex (reaction (4)) ${ }^{a}$

\begin{tabular}{lrrrr}
\hline & $\Delta H_{\mathrm{aq}}$ & $\Delta G_{\mathrm{aq}}$ & $\Delta \Delta H_{\mathrm{aq}}$ & $\Delta \Delta G_{\mathrm{aq}}$ \\
\hline $\mathrm{Al} \cdot \mathrm{Pept}^{9}{ }_{3 \mathrm{G}}$ & -25.9 & -97.0 & 0.0 & 0.0 \\
$\mathrm{Al} \cdot \mathrm{Pept}^{9}{ }_{\mathrm{GPG}}$ & 6.5 & -70.3 & 32.4 & 26.6 \\
$\mathrm{Al} \cdot \mathrm{Pept}^{8}{ }_{\text {GG-3G }}$ & -8.8 & -80.2 & 17.1 & 16.7 \\
$\mathrm{Al} \cdot \mathrm{Pept}^{8}{ }_{3 \mathrm{G}-2 \mathrm{G}}$ & -21.7 & -90.3 & 4.2 & 6.6 \\
$\mathrm{Al} \cdot \mathrm{Pept}^{7}$ (C.N. $\left.=6\right)$ & -3.0 & -72.6 & 23.0 & 24.4 \\
$\mathrm{Al} \cdot \mathrm{Pept}^{7}$ (C.N. $\left.=5\right)$ & -1.0 & -73.2 & 25.0 & 23.7 \\
$\mathrm{Al} \cdot \mathrm{Pept}^{6}{ }_{\mathrm{G}-2 \mathrm{G}}$ & 14.9 & -59.6 & 40.8 & 37.4 \\
$\mathrm{Al} \cdot \mathrm{Pept}^{6}{ }_{\text {GG-G }}$ & 1.8 & -70.2 & 27.7 & 26.8 \\
$\mathrm{Al} \cdot \mathrm{Pept}^{5}$ & -8.2 & -73.8 & 17.8 & 23.2 \\
$\mathrm{Al} \cdot \mathrm{DFP}_{3}$ & -28.8 & -84.0 & -2.9 & 13.0
\end{tabular}

${ }^{a}$ The relative $\Delta \Delta H_{\text {aq }}$ and $\Delta \Delta G_{\text {aq }}$ values, taking $\operatorname{Pept}^{9}{ }_{3 \mathrm{G}}$ as reference, are also shown. All energies in $\mathrm{kcal}^{\mathrm{mol}}{ }^{-1}$.

$\Delta \Delta H_{\mathrm{aq}}$ and $\Delta \Delta G_{\mathrm{aq}}$ values, indicating that the change in entropy is similar for each of the eight complexes. However, a large difference is observed between the $\Delta H_{\mathrm{aq}}$ and $\Delta G_{\mathrm{aq}}$ values, what points to a large entropic contribution in the formation of each compound. However, it should bear in mind that in reaction (3) there are more product species than reactants $(\Delta n=5)$, and that they are considered infinitively separated, leading to an overestimation of the entropy contribution. Hence, for absolute values the $\Delta H_{\text {aq }}$ values are more trustable, although we remark that the relative $\Delta \Delta G_{\mathrm{aq}}$ values are also useful to confirm similar entropic effects for all complexes.

Hence, we focus on the $\Delta \Delta H_{\mathrm{aq}}$ values. In overall, the trend in the relative energies computed with DFT is similar to the one obtained from the QM/MM MD simulations, albeit the values are larger with DFT, i.e., $\mathrm{Al} \cdot \mathrm{Pept}^{9}{ }_{3 \mathrm{G}}$ is more stable with DFT. The results confirm that the complexes formed by the longest peptides are more stable than the ones formed by the shortest peptides, even though there are some exceptions (see below). The three most stable complexes correspond to the longest peptides: $\mathrm{Al} \cdot \mathrm{Pept}_{3 \mathrm{G}}\left(\Delta \Delta H_{\mathrm{aq}}=0.0 \mathrm{kcal} \mathrm{mol}^{-1}\right), \mathrm{Al} \cdot \mathrm{Pept}^{8}{ }_{3 \mathrm{G}-2 \mathrm{G}}$ $\left(\Delta \Delta H_{\mathrm{aq}}=4.2 \mathrm{kcal} \mathrm{mol}^{-1}\right)$ and $\mathrm{Al} \cdot \mathrm{Pept}^{8}{ }_{2 \mathrm{G}-3 \mathrm{G}}\left(\Delta \Delta H_{\mathrm{aq}}=\right.$ $\left.17.1 \mathrm{kcal} \mathrm{mol}^{-1}\right)$. On the other hand, $\mathrm{Al} \cdot \mathrm{Pept}^{6}{ }_{\mathrm{G}-2 \mathrm{G}}$ is the less stable complex $\left(\Delta \Delta H_{\mathrm{aq}}=40.8 \mathrm{kcal} \mathrm{mol}^{-1}\right)$, whereas the $\Delta \Delta H_{\mathrm{aq}}$ values of the remaining five complexes are in the 23.0/ $32.4 \mathrm{kcal} \mathrm{mol}^{-1}$ range.

However, there are some remarkable differences between the stability trends obtained from DFT and MD calculations. The $\mathrm{Al} \cdot \mathrm{Pept}^{9}{ }_{\text {GPG }}$ complex is significantly less stable with DFT $\left(\Delta \Delta H_{\mathrm{aq}}=32.4 \mathrm{kcal} \mathrm{mol}^{-1}\right)$ than the value computed from MD simulation $\left(\Delta \Delta H_{\mathrm{aq}}=1.8 \mathrm{kcal} \mathrm{mol}^{-1}\right)$. Al $\cdot \mathrm{Pept}^{6}{ }_{\mathrm{G}-2 \mathrm{G}}$ is also much less stable with DFT (40.8 vs. $12.9 \mathrm{kcal} \mathrm{mol}^{-1}$ ), whereas $\mathrm{Al} \cdot \mathrm{Pept}^{5}$ is more stable (17.8 vs. $\left.20.0 \mathrm{kcal} \mathrm{mol}^{-1}\right)$. It must point out that the two set of energies were obtained by different approaches. The DFT energies, which are computationally more demanding, are based on a unique structure. Alternatively, the QM/MM $\Delta \Delta H_{\text {aq }}$ values were averaged over all the frames stored in the trajectories, what provides a better sampling of the system, particularly important with the more flexible aporforms of the peptides. Nevertheless, the high level DFT energies are useful 
for two main reasons. Firstly, the data collected by this method, which is conceptually more robust than the PM6 semiempirical method, support the energy trends obtained with PM6 (see Table S14 $\dagger$ ). Secondly, we can compare directly the stability of the $\mathrm{Al} \cdot \mathrm{Pept}$ complexes and $\mathrm{Al} \cdot \mathrm{DFP}_{3}$. As it can be seen in Table 3,

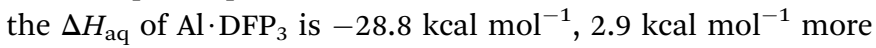
stable than $\mathrm{Al} \cdot \mathrm{Pept}^{9}{ }_{3 \mathrm{G}}$. Note that the entropic penalty is larger with $\mathrm{Al} \cdot \mathrm{DFP}_{3}$, but this is expected due to the complexation of three infinitively separated DFP molecules, whereas with the peptides the three mimosine residues belong to the same molecule. All in all, these results suggest that $\mathrm{Pept}^{9}{ }_{3 \mathrm{G}}$ can compete with DFP as efficient chelator of $\mathrm{Al}(\mathrm{III})$.

We also analyze the metal binding sites of $\mathrm{Al} \cdot \mathrm{DFP}_{3}$ and $\mathrm{Al} \cdot \mathrm{Pept}^{9}{ }_{3 \mathrm{G}}$ by comparing the distances and angles of three structures (shown in Fig. $\mathrm{S} 1$ and $\mathrm{S} 2, \dagger$ data in Table S1 $\dagger$ ): (i) experimental structure of the $\mathrm{Al} \cdot \mathrm{DFP}_{3}$ complex crystallized in water, ${ }^{\mathbf{4 3}}$ (ii) the $\mathrm{Al} \cdot \mathrm{DFP}_{3}$ complex optimized by a DFT high level quantum method, $\dagger$ and (iii) a DFT optimized structure of Al $\cdot \mathrm{Pept}^{9}{ }_{3 \mathrm{G}}$. Regarding the $\mathrm{Al} \cdot \mathrm{DFP}_{3}$ complex, the DFT structure is equivalent to the experimental one, although the six $\mathrm{Al}-\mathrm{O}$ distances computed on the DFT optimized structures are systematically $0.02 \AA$ longer than in the X-ray structure. The computed angles are also very similar, with differences less than 1 degree between the experimental and theoretical $\mathrm{Al} \cdot \mathrm{DFP}_{3}$ structures. On the other hand, the distances computed on the $\mathrm{Al} \cdot \mathrm{DFP}_{3}$ and $\mathrm{Al} \cdot \mathrm{Pept}^{9}{ }_{3 \mathrm{G}}$ structures optimized with DFT, are also very similar. The electron delocalization indices, which describe the electronic arrangement of the metal first coordination shell, were also computed on the two DFT structures (see Table S15 $\dagger$ ), showing equivalent values. All in all, all these evidences support the fact that the interactions between $\mathrm{Al}(\mathrm{III})$ and $\mathrm{Pept}^{9}{ }_{3 \mathrm{G}}$ mimics the ones at the $\mathrm{Al} \cdot \mathrm{DFP}_{3}$ complex, and that the peptide backbone does not influence substantially the position of the three pyrodine rings.

\section{Conclusions}

In the present study we explore the adequacy of a new family of high-valent metal chelators, based on mimosine containing polypeptides, as efficient chelator of $\mathrm{Al}(\mathrm{III})$. We analyze the structural and energetic stability of the complexes formed by $\mathrm{Al}(\mathrm{III})$ with several mimosine containing peptides of different lengths and sequences, going from the shortest polypeptide of five amino acids to the largest ones with nine residues.

The results reveal that the longest four peptides, made of 8 and 9 residues, show no difficulties for a hexadentate interaction with $\mathrm{Al}(\mathrm{III})$. A comparative analysis of the geometrical and electronic features characterized for these complexes reveals $\mathrm{Al}-$ $\mathrm{O}$ interactions very similar to the ones found in $\mathrm{Al} \cdot \mathrm{DFP}_{3}$. The geometrical analysis indicates that the ligands of the cation are posed in a near-optimum octahedral arrangement, very similar to the disposition adopted by the aromatic rings in the $\mathrm{Al} \cdot \mathrm{DFP}_{3}$ complex. In addition, thermodynamically the $\mathrm{Al} \cdot \mathrm{Pept}^{9}{ }_{3 \mathrm{G}}$ complex is almost as stable as $\mathrm{Al} \cdot \mathrm{DFP}_{3}$. On the other hand, the shortest three peptides, with only five or six residues, are too short to place the side chains of the three mimosine residues in the right position to form six stable interactions with the cation. Consequently, the central mimosine is a monodentate ligand so that only five mimosine oxygen atoms interact with $\mathrm{Al}(\mathrm{III})$. Finally, the $\mathrm{Pept}^{7}$ peptide is in the borderline, as during the QM/ MM MD simulation of its complex both coordination modes are sampled, that is, with $\mathrm{Al}(\mathrm{III})$-penta- or hexacoordinated. During the simulation the octahedral arrangement is predominant, but the stability of the complex formed by this peptide is lower than the ones formed by the longest peptides.

The results presented herein point to a direct correlation between peptide length, metal coordination number and complex stability. Thus, the four complexes with $\mathrm{Al}(\mathrm{III})$ octahedral are clearly the most stable ones. The relative energies of all these

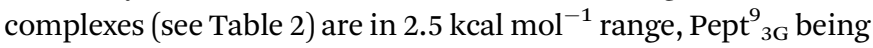
the most stable one. On the other hand, with the remaining peptides, the shorter the peptide, the less stable the complex, so that the stability trend is: $\mathrm{Pept}^{7}>\mathrm{Pept}^{6}>\mathrm{Pept}^{5}$. Among them, $\mathrm{Pept}^{7}$ is the most stable one, $11.4 \mathrm{kcal} \mathrm{mol}^{-1}$ less stable than Pept $^{9}{ }_{3 \mathrm{G}}$. This trend suggests that a larger peptide would certainly increase its affinity towards $\mathrm{Al}(\mathrm{III})$. Nevertheless, we remark that a good chelator requires an optimum balance between the affinity towards the metal and its size, which must be as small as possible to allow an efficient crossing of the molecule across the membrane. Based on these prerequisites, we believe the longest peptides considered in this work, and more in particular Pept ${ }_{3 \mathrm{G}}{ }_{3}$, emerges as the best potential mimosine containing chelator of $\mathrm{Al}(\mathrm{III})$, since this peptide are relatively small and provides an optimum interaction mode with the cation.

In summary, the computational study presented herein provides a deep description of the interaction between $\mathrm{Al}(\mathrm{III})$ and mimosine containing peptides, and provide notable atomistic details about the interaction between the peptide and the cation. The present results can encourage further experimental characterization of these polypeptides which we predict has promising properties to chelate not only aluminum, but also highly-charged metals such as Fe(III) that show octahedral coordination and that for which Deferiprone is a good chelator.

\section{Conflicts of interest}

There are no conflicts to declare.

\section{Acknowledgements}

This research has been funded by the Spanish MINECO/FEDER Projects CTQ2015-67608-P (X. L.) and the Basque Country Consolidated Group Project No. IT588-13. The authors would like to thank the technical and human support provided by the SGI/IZO (SGIker) of the UPV/EHU. Financial support comes as well from the European Commission, Horizon 2020 Research and Innovation Programme (grant agreement N 642294-TCCM).

\section{Notes and references}

$1 \mathrm{~J}$. W. Richards, Aluminium; its history, occurrence, properties, metallurgy and applications, including its alloys, H. C. Baird \& Co., Philadelphia, 1896.

2 J. Kopáček, J. Hejzlar, J. Kaňa, S. A. Norton, P. Porcal and J. Turek, J. Inorg. Biochem., 2009, 103, 1439-1448. 
3 G. Crisponi, D. Fanni, C. Gerosa, S. Nemolato, V. M. Nurchi, M. Crespo-Alonso, J. I. Lachowicz and G. Faa, Biomol. Concepts, 2013, 4, 77-87.

4 A. C. Alfrey, G. R. LeGendre and W. D. Kaehny, N. Engl. J. Med., 1976, 294, 184-188.

5 D. A. Bushinsky, S. M. Sprague, P. Hallegot, C. Girod, J. M. Chabala and R. Levi-Setti, J. Bone Miner. Res., 2009, 10, 1988-1997.

6 M. Touam, F. Martinez, B. Lacour, R. Bourdon, J. Zingraff, S. Di Giulio and T. Drüeke, Clin. Nephrol., 1983, 19, 295-298.

7 A. Campbell and S. C. Bondy, Cell. Mol. Biol., 2000, 46, 721-730. 8 J. Aaseth, G. Crisponi and O. Anderson, Chelation Therapy in the Treatment of Metal Intoxication, 1st edn, 2016.

9 M. A. Canteros-Piccotto, J. L. Fernandez-Martin, M. J. Cannata-Ortiz and J. B. Cannata-Andia, Nephrol., Dial., Transplant., 1996, 11, 1488-1489.

10 W. C. Kan, C. C. Chien, C. C. Wu, S. B. Su, J. C. Hwang and H. Y. Wang, Nephrol., Dial., Transplant., 2010, 25, 1604-1608. 11 R. A. Yokel, Coord. Chem. Rev., 2002, 228, 97-113.

12 T. Zhou, Y. Ma, X. Kong and R. C. Hider, Dalton Trans., 2012, 41, 6371-6389.

13 Y. Ma, T. Zhou, X. Kong and R. C. Hider, Curr. Med. Chem., 2012, 19, 2816-2827.

14 A. Cilibrizzi, V. Abbate, Y.-L. Chen, Y. Ma, T. Zhou and R. C. Hider, Chem. Rev., 2018, 118, 7657-7701.

15 S. Chaves, S. M. Marques, A. M. Matos, A. Nunes, L. Gano, T. Tuccinardi, A. Martinelli and M. A. Santos, Chem.-Eur. J., 2010, 16, 10535-10545.

16 R. Grazina, L. Gano, J. Šebestík and M. Amelia Santos, J. Inorg. Biochem., 2009, 103, 262-273.

17 R. Cappai, K. Chand, J. I. Lachowicz, S. Chaves, L. Gano, G. Crisponi, V. M. Nurchi, M. Peana, M. A. Zoroddu and M. A. Santos, New J. Chem., 2018, 42, 8050-8061.

18 R. Cusnir, C. Imberti, R. Hider, P. Blower, M. Ma, R. Cusnir, C. Imberti, R. C. Hider, P. J. Blower and M. T. Ma, Int. J. Mol. Sci., 2017, 18, 116.

19 D. J. Berry, Y. Ma, J. R. Ballinger, R. Tavaré, A. Koers, K. Sunassee, T. Zhou, S. Nawaz, G. E. D. Mullen, R. C. Hider and P. J. Blower, Chem. Commun., 2011, 47, 7068-7070.

20 V. Abbate, O. Reelfs, X. Kong, C. Pourzand and R. C. Hider, Chem. Commun., 2015, 52, 784-787.

21 B. C. Q. Nguyen and S. Tawata, Phytother. Res., 2016, 30, 1230-1242.

22 M. Lalande, Exp. Cell Res., 1990, 186, 332-339.

23 A. Upadhyay, J. Chompoo, N. Taira, M. Fukuta, S. Gima and S. Tawata, J. Agric. Food Chem., 2011, 59, 12858-12863.

24 B. C. Q. Nguyen and S. Tawata, Molecules, 2016, 30, 12301242.

25 B. Z. Mascaliovas, F. R. G. Bergamini, A. Cuin and P. P. Corbi, Powder Diffr., 2015, 30, 357-361.

26 E. Chruscinska, J. Inorg. Biochem., 1999, 75, 225-232.

27 R. C. Scarrow, P. E. Riley, K. Abu-Dari, D. L. White and K. N. Raymond, Inorg. Chem., 1985, 24, 954-967.

28 M. a Telpoukhovskaia, C. Rodríguez-Rodríguez, L. E. Scott, B. D. G. Page, B. O. Patrick and C. Orvig, J. Inorg. Biochem., 2014, 132, 59-66.
29 D. A. Case, V. Babin, J. T. Berryman, R. M. Betz, Q. Cai, D. S. Cerutti, T. E. Cheatham III, T. A. Darden, R. E. Duke, H. Gohlke, A. W. Goetz, S. Gusarov, N. Homeyer, P. Janowski, J. Kaus, I. Kolossváry, A. Kovalenko, T. S. Lee, S. LeGrand, T. Luchko, R. Luo, B. Madej, K. M. Merz, F. Paesani, D. R. Roe, A. Roitberg, C. Sagui, R. SalomonFerrer, G. Seabra, C. L. Simmerling, W. Smith, J. Swails, R. C. Walker, J. Wang, R. M. Wolf, X. Wu and P. A. Kollman, AMBER 14, University of California, San Francisco, 2014.

30 J. J. P. Stewart, J. Mol. Model., 2007, 13, 1173-1213.

31 J. A. Maier, C. Martinez, K. Kasavajhala, L. Wickstrom, K. E. Hauser and C. Simmerling, J. Chem. Theory Comput., 2015, 11, 3696-3713.

32 W. L. Jorgensen, J. Chandrasekhar, J. D. Madura, R. W. Impey and M. L. Klein, J. Chem. Phys., 1983, 79, 926935.

33 J. P. Ryckaert, G. Ciccotti and H. J. C. Berendsen, J. Comp. Physiol., 1977, 23, 327-341.

34 T. Darden, D. York and L. Pedersen, J. Chem. Phys., 1993, 98, 10089-10092.

35 U. Essmann, L. Perera, M. L. Berkowitz, T. Darden, H. Lee and L. G. Pedersen, J. Chem. Phys., 1995, 103, 8577-8592.

36 D. R. Roe and T. E. Cheatham, J. Chem. Theory Comput., 2013, 9, 3084-3095.

37 D. Bashford and D. A. Case, Annu. Rev. Phys. Chem., 2000, 51, 129-152.

38 H. Yadegari, A. Jabbari, H. Heli, A. A. Moosavi-Movahedi and S. Majdi, J. Braz. Chem. Soc., 2008, 19, 1017-1022.

39 J. I. Mujika, J. M. Ugalde and X. Lopez, Theor. Chem. Acc., 2010, 128, 477-484.

40 M. J. Frisch, G. W. Trucks, H. B. Schlegel, G. E. Scuseria, M. A. Robb, J. R. Cheeseman, G. Scalmani, V. Barone, G. A. Petersson, H. Nakatsuji, X. Li, M. Caricato, A. V. Marenich, J. Bloino, B. G. Janesko, R. Gomperts, B. Mennucci, H. P. Hratchian, J. V. Ortiz, A. F. Izmaylov, J. L. Sonnenberg, D. Williams-Young, F. Ding, F. Lipparini, F. Egidi, J. Goings, B. Peng, A. Petrone, T. Henderson, D. Ranasinghe, V. G. Zakrzewski, J. Gao, N. Rega, G. Zheng, W. Liang, M. Hada, M. Ehara, K. Toyota, R. Fukuda, J. Hasegawa, M. Ishida, T. Nakajima, Y. Honda, O. Kitao, H. Nakai, T. Vreven, K. Throssell, J. A. Montgomery Jr, J. E. Peralta, F. Ogliaro, M. J. Bearpark, J. J. Heyd, E. N. Brothers, K. N. Kudin, V. N. Staroverov, T. A. Keith, R. Kobayashi, J. Normand, K. Raghavachari, A. P. Rendell, J. C. Burant, S. S. Iyengar, J. Tomasi, M. Cossi, J. M. Millam, M. Klene, C. Adamo, R. Cammi, J. W. Ochterski, R. L. Martin, K. Morokuma, O. Farkas, J. B. Foresman and D. J. Fox, Gaussian16 Revision A.03.

41 J. Tomasi, B. Mennucci and R. Cammi, Chem. Rev., 2005, 2999-3093.

42 M. W. Palascak and G. C. Shields, J. Phys. Chem. A, 2004, 108, 3692-3694.

43 W. O. Nelson, S. J. Rettig and C. Orvig, J. Am. Chem. Soc., 1987, 109, 4121-4123. 